\title{
TEOLOGIA POWOEANIA CHRZEŚCIJAŃSKIEGO W JEGO WYMIARZE WSPÓLNOTOWYM
}

\author{
1. OKRESLENIE POWOEANIA CHRZEŚCIJAŃSKIEGO NA TLE \\ JEGO ZWIĄZKU Z INTEGR ALNYM POWOEANIEM CZEOWIEKA
}

Teologiczna literatura ostatniego dziesięciolecia na temat powołania człowieka, to głównie komentarze do soborowej Konstytucji o Kościele w świecie współczesnym lub opracowania ściśle do niej nawiązujące oraz prace biblijne ${ }^{1}$.

Sobór nie określił jednak wprost powołania chrześcijańskiego, ale mówił o powołaniu człowieka w ogóle, nie starając się o ścisłe jego zdefiniowanie i nazywając je powołaniem integrálny m, integra vocatio hominis ${ }^{2}$, czy też o poszczególnych aspektach powołania ujętego ogólnie. Fow lanie człowieka jest zasadniczo j edno, ale zawiera w sobie dwa, nie dające się rozdzielić aspekty: natury i łaski z tym, że powołanie $\mathrm{w}$ aspekcie natury skierowane jest $\mathrm{ku}$ realizacji powołania W aspekcie łaski i dlatego - jak wykazuje ks. B. Inlender ${ }^{3}-$ powołarie człowieka ze swej istoty jest nadprzyrodzone czyli chrześcijańskie. Z tego powiązania wynika, że powołania chrześcijańskiego nie można oddzielić od całości owo pojętego powołania człowieka ani nie można go określić inaczej jak tylko na jego tle.

Powołanie człowieka rozpoczęło się $\mathrm{w}$ akcie stworzenia go jako osoby czyli istoty rozumnej i wolnej, ,przeznaczonej do świadomego tworzenia i wykorzystania widzialnego świata dla swojego rozwoju" (KDK 24; por. 12, 34). Działalność człowieka na płaszczyźnie natury, służąca także

1 Artykuł ten umieszczony był w „Częstochowskich Wiadomościach Diecezjalnych" 48 (1974) $\mathrm{nr} 8 / 9,177-190$.

2 DM 8. Por. Ks. bp St. Smoleński, Teologia moralna powołania chrześcijańskiego, „Analecta Cracoviensia”, 2 1970) 203; Ks. B. Inlender, Nadprzyrodzone powotanie człowieka, ,Ateneum Kapl.”, 62 (1970), t. 74, 200.

3 Art. cyt., 207. 
jego rozwojowi, ma prowadzić ku Bogu, ponieważ Bóg przeznaczył człowieka również do udziału w swoim własnym Bożym życiu i szczęściu. „Oscbliwą rację godności ludzkiej - wyjaśnia Sobór - stanowi powolanie człowieka do uczestnictwa w życiu Boga. Człowiek już od początku zapraszany jest do rozmowy z Bogiem" (KDK 19; por. 17).

Z woli Boga-Stwórcy powołanie człowieka obejmuje zarówno jego przeznaczenie do tworzenia ziemskich, doczesnych wartości, służących rozwojowi człowieka, jak również i jego powołanie do wspólnoty z Bogiem i do udziału w Jego szczęściu, przy czym to ostatnie ,nie pomniejsza zadań ziemskich, lecz raczej wspiera ich spełnianie nowymi pobudkami" (KDK 21). Powołanie .człowieka posiada więc d"w a w y mia ry: doczesny i ziemski oraz ostateczny i nadprzyrodzony, które są ze sobą bardzo ściśle powiązane. Powołanie nadprzyrodzone nie przeszkadza realizacji powołania doczesnego, ale to ostatnie jest podporządkowane pierwszemu.

Realizacja pierwotnego, można by powiedzieć stwórczego przeznaczenia i powołania w aspekcie nadprzyrodzonym napotkała przeszkodę w grzechowym upadku człowieka. Przezwyciężenie tej przeszkody stało się możliwe dzięki Jezusowi Chrystusowi, który wyzwolił człowieka z niewoli grzechowej (por. KDK 2). Odtąd stwórcze, pierwotne powołanie człowieka staje się także powołaniem odkupieńczym albo - inaczej mówiąc - powołaniem w ścisłym znaczeniu chrześci ja ńskim, a to dlatego, ponieważ w ekonomii zbawienia upadłego człowieka, może zostać ono zrealizowane tylko dzięki odkupieniu Chrystusa.

W konstytuowaniu się chrześcijańskiego powołania, jak i w jego realizowaniu, istotną rolę odgrywa również Kościół, ponieważ za jego pośrednictwem rozdziela Chrystus owoce swego odkupienia. $Z$ tego powodu Sobór mógł powiedzieć, że Kościół jest w Chrystusie niejako sakramentem czyli znakiem i narzędziem wewnętrznego zjednoczenia z Bogiem (KK 1). Powołanie chrześcijańskie obejmuje także i powołanie do K o ś c i o ła, które jest tak samo powszechne i skierowane do wszystkich ludzi jak i pierwotne powołanie do uczestniczenia w życiu i szczęściu Bożym.

Chrześcijańskie powołanie można ok reśli ć ${ }^{4}$ jako naturalne i nadprzyrodzone wyposażenie, udzielone człowiekowi przez Boga w akcie stworzenia i odkupienia, wzywające człowieka do uczestnictwa w życiu i szczęściu Bożym oraz umożliwiające mu osiągnięcie tego celu w łączności z Chrystusem i z założonym przez Niego Kościołem. Chodzi tu o najogólniejsze zarysowanie pojęcia chrześcijańskiego powołania, o uchwycenie tych elementów, które występują - jako podstawowe -

${ }^{4}$ Por. Ks. bp St. Smoleński, art. cyt., 189, 203. 
we wszystkich szczegółowych, osobistych powołaniach skierowanych do każdego, indywidualnie wziętego człowieka.

Zarówno integralne powołanie człowieka, jak i powołanie chrześcijańskie mają charakter wyraźnie personalistyczny, ponieważ są osobistym zaproszeniem Boga skierowanym osobiście do każdego człowieka i stanowią o godności osoby ludzkiej ${ }^{5}$. Nie jest to jednak równoznaczne z jakimś przesadnym indywidualizmem. Chrześcijańskie powołanie posiada bowiem także wymiar społeczny, w s pó l n o t o w y, na który chce wskazać obecny artykuł, przez wydobycie wspólnotowego aspektu w poszczególnych etapach kształtowania się powołania chrześcijańskiego a mianowicie w akcie stworzenia, odkupienia $\mathrm{i} w$ związanym $\mathrm{z}$ nim powołaniu do Kościoła.

\section{WSPOLNOTOWY ASPEKT POWOEANIA W AKCIE STWORZENIA}

Mówiąc o powołaniu człowieka w akcie s t w o r z e n i. a, podkreśla się zwykle, za Konstytucją Gaudium et spes (por. 12), stworzenie człowieka na obraz Boży oraz stworzenie go jako mężczyznę i kobietę (por. Rdz 1, 27).

Gdy chodzi o stworzenie na obraz Boży, to - pozostawiając na boku całą jego interpretację biblijną i patrystyczną - należy zwrócić uwagę, że już ono wskazuje na wspólnotowy element powołania czy przeznaczenia człowieka. Został on bowiem stworzony na obraz Boga, który ż y je ws pólnotow y m ż y c i e m i dlatego człowiek z natury przeznaczony jest do życia w społeczności, a rodzina Boża stała się modelem rodziny ludzkiej ${ }^{6}$. Stwierdza to również Sobór, kiedy mówi ,o pewnym podobieństwie między jednością osób Boskich a jednością synów Bożych zespolonych w prawdzie i miłości” (KDK 24).

P. Haubtmann ${ }^{7}$, tragicznie zmarły przed paru laty Rektor Katolickiego Instytutu w Paryżu, zwraca uwage, że u genezy powyższego sformułowania znajduje się dyskusja pomiędzy ekspertami soborowymi, w której dochodziło do głosu powiązanie ws pólnotowej natury osoby ludzkiej i jej przeznaczenia wprost z samą tajemnicą Trójcy Świętej. Wiara chrześcijańska uczy, że istnieje jeden Bóg oraz że istnieją również trzy Osoby Boskie, z których każda żyje dla drugich Osób i to do tego stopnia, że Osoby w Trójcy Świętej konstytuują się przez odniesienie czyli przez relację do pozostałych Osób. „Te trzy Osoby są jednym Bogiem... wyjaśnia dekret unijny dla Jakobitów na Soborze Florenckim - ponie-

5 Na temat godności osoby ludzkiej por. Ks. T. Slipko SJ, Godność osoby ludzkiej, ,Ateneum Kapl.”, tamże, 185-195.

6 "Por. Ks. J. Kowalski, Człowiek jako obraz Boży w świetle Konstytucji Gaudium et spes, „Częstochowskie Studia Teologiczne”, 1 (1973) 120.

7 La communauté humaine, w: Y. Congar et 'M. Peuchmard, L'Église dans le monde de ce temps, Paris 1967, (Unam sanctam 65b), t. 2, $267 \mathrm{n}$. 
waż mają jedną substancję, jedną istotę, jedną naturę... i wszystko jest w nich jednym, gdzie nie zachodzi przeciwstawność relacji" ${ }^{8}$. Wszystko jest $\mathrm{w}$ nich jednym, można powiedzieć, $\mathrm{z}$ wyjątkiem przeciwstawnych odniesień Ojca do Syna oraz Ojca i Syna do Ducha Swiętego. Jedyna różnica między Osobami Trójcy Swiętej to przeciwstawne relacje i one konstytuują Osoby Boże.

Skoro człowiek jest także osobą, stworzoną na obraz Boga, Boga Jedynego i Trójosobowego - argumentowali soborowi eksperci - to musi nosić $w$ sobie i to podobieństwo, że istnieje nie tylko dla siebi e ale i dla drugich osób. Ponieważ większość ekspertów - zdaniem Haubtmanna - była przywiązana do scholastycznej koncepcji osoby, która to koncepcja pojmuje osobę bardziej jako byt in se niż jako byt ad alios, dlatego w końcowym tekście soborowego dokumentu ścieniowano to porównanie, mówiąc tylko o pewnym podobieństwie między jednością Osób Boskich a jednością przybranych synów Bożych.

W końcowym zdaniu artykułu 24 Konstytucji Gaudium et spes dochodzi jednak do głosu, wydaje się, dyskutowana analogia, kiedy Konstytucja stwierdza, że człowiek ,nie może odnaleźć się w pełni inaczej jak tylko poprzez bezinteresowny dar z siebie samego" (KDK 24), czyli do natury człowieka, rozwiniętej w pełni, należy dawanie samego siebie ale tylko przynajmniej równemu sobie, to jest drugiej osobie.

I faktycznie człowiek od chwili stworzenia został przeznaczony i powołany do wspólnotowego życia. „Lecz Bóg nie stworzył człowieka samotnym: gdyż od początku - wyjaśnia Konstytucja Gaudium et spes mężczyznę i niewiastę stworzył ich (Rdz 1, 27); a zespolenie ich stanowi pierwszą formę wspólnoty osób. Człowiek bowiem z głębi swej natury jest istotą społeczną, toteż bez stosunków z innymi ludźmi nie może ani żyć, ani rozwinąć swoich uzdolnień" (KDK 12). Innymi słowy, u podstaw pianów Bożych wobec człowieka leży ży ci e społeczne czyli ws pólnotowe, oparte na braterstwie, ponieważ wszyscy ludzie są pod tym względem sobie równi (por. KK 32), i na miłości. Stąd „,miłość Boga i bliźniego jest pierwszym i najważniejszym przykazaniem" (KDK 24).

Nie ma potrzeby dowodzić tutaj twierdzenia, że człowiek z natury swojej przeznaczony został do życia wspólnotowego z innymi ludźmi, które umożliwia mu dopiero rozwinięcie swojej osobowości i uzdolnień ${ }^{9}$.

Człowiek został przeznaczony i powołany nie tylko do wspólnoty $\mathrm{w}$ kierunku horyzontalnym z drugim c złowiekiem, ale i w kierunku wertykalnym, ponieważ został powołany, i to przede wszystkim, „jakło syn do samej wspólnoty (communio) z Bogiem i do udziału w Jego

8 DS 1330. Tłumaczenie polskie według Breviarum fidei, IV, 73.

9 Por. Ks. kard. K. Wojtyła, U podstaw odnowy, Kraków 1972, 103; Ks. J. Kowalski, art. cyt., 120. 
szczęściu” (KDK 21). Chodzi tu o powołanie nadprzyrodzone, ponieważ Bóg powołuje człowieka do tak ścisłej ze Sobą wspólnoty (która polega na udziale w Bożym życiu i uczestniczeniu w Bożym szczęściu), że w żaden sposób człowiek nie może mieć do tego prawa na podstawie samej tylko swojej natury ${ }^{10}$. „Osobliwą rację godności ludzkiej — stwierdza Konstytucja Gaudium et spes - stancwi powołanie człowieka do uczestniczenia w życiu Boga. Człowiek już od swego początku - wyjaśnia Sobór - zapraszany jest do rozmowy z Bogiem: istnieje bowiem tylko dlatego, że Bóg stworzył go z miłości i wciąż z miłości zachowuje, a żyje w pełni wedle prawdy, gdy dobrowolnie uznaje ową miłość i powierza się swemu Stwórcy..." (KDK 19; por. KO 2).

Powołaniu do wspólnoty ze strony Boga ma odpowiedzieć dobrowolne - ze strony człowieka - uznanie miłości Boga, zawierzenie Bogu i dążenie do Niego całym życiem, do czego skłania człowieka ciągła tęsknota za Bogiem, wpisana niejako w samą naturę człowieka.

Sobór (por. KDK 21) i niektórzy teologowie ${ }^{11} \mathrm{w}$ uzasadnieniu powyższego stwierdzenia odwolują się do wypowiedzi św. A u gustyna, gdy pisze: ,stworzyleś nas dla siebie (Boże) i niespokojne jest serce nasze, dopóki nie spocznie w Tobie" ${ }^{12}$. „To tylko wiem, że jest mi źle bez Ciebie - pisze nieco dalej św. Augustyn - nie tylko na zewnątrz, ale i we mnie samym, a wszelkie bogactwo, które nie jest Bogiem moim, ubóstwem jest dla mnie" ${ }^{13}$. We wnętrzu człowieka odzywa się jakaś pustka, którą zapełnić może tylko sam Bóg. Człowiek dopiero wtedy czuje się szczęśliwy - według przekonania Biskupa z Hippony - gdy Boga umiłuje i zazna Jego szczęścia. Widzenie, jakie ze św. Moniką przeżył w Ostii, zaczęło dopiero uciszać „niepokój ich serca” ${ }^{14}$.

O niepokoju, który pcha człowieka do szukania Boga jako źródła szczęścia, mówi wielokrotnie Pismo święte ${ }^{15}$. „O jedno proszę Jahwe, tego poszukuję - woła Psalmista - bym w domu Jahwe przebywał po wszystkie dni mego życia, abym zażywał łaskawości ,stale się radował Jego świątynią” (Ps 27,4), dodając kilka wierszy później: „O Tobie mówi moje serce: Szukaj Jego oblicza. Szukam o Jahwe, Twojego oblicza" (Ps. 27, 8).

Wprawdzie przytoczone teksty nawiązują bezpośrednio do starotestamentalnej liturgii, ale wyrażają z pewnością pragnienie człowieka do

${ }_{10}$ Por. Ks. B. Inlender, art. cyt., 199.

$11 \mathrm{~Np}$. L. Malavez, L'intériodité et gratuité de la vocation chrétienne, „Ephemerides Theologicae Lovanienses", 48 (1972), fasc. 1, $52 \mathrm{n}$.

12. Wyznania 1, 1. Tłumaczenie polskie wg Ks. J. Czuja, Kraków $1949^{2}$.

13 Tamże 13, 8. Tłum. polskie, 379.

14 Tamże 9, 10. Tłum. polskie, 379.

15 Temat ten omawiają: L, Malevez, art. cyt., 53-54; J. Goldstein, La vocation de l'homme, „La vie spirituelle”, 120 (1969) 17-18; Ks. J. Stępień, Biblijna idea powołania człowieka, w: Ks. bp B. Bejze, W kierunku człowieka, Warszawa 1971, $124-125$. 
przebywania w obecności Boga, do obcowania z Nim. Zresztą cały Stary Testament, jak twierdzi X. Leon-Dufour ${ }^{16}$, jest przeniknięty bardzo głębokim pragnieniem Boga, które jest zdolne przezwyciężyć wszystkie niepowodzenia. „Któż poza Tobą jest dla mnie we mnie - przytacza wspomniany biblista na dowód swojej tezy słowa psalmisty - Gdy jestem z Tobą, nie cieszy mnie ziemia. Niszczeje me ciało i serce, Bóg jest opoką mego serca i mym udziałem w wieczności" (Ps 73, 25 n).

Również i św. Paweł w mowie na Areopagu daje wyraz przekonaniu o powszechnym dążeniu ludzi do szukania i odkrywania Boga oraz łączy je już ze stworzeniem człowieka przez Boga (por. Dz. 17, 27-28).

Można - na podstawie przytoczonych argumentów - zgodzić się $\mathrm{z}$ wnioskiem L. M a levez' a ${ }^{17}$, że równolegle do powszechnego przeznaczenia i powołania człowieka do uczestniczenia w życiu i szczęściu Bożym, stnieje w człowieku bardzo dynamiczne pragnienie szukania Boga. Bez obcowania z Bogiem człowiek wciąż bowiem odczuwa niepokój swego serca. Dopiero gdy dochodzi do oglądania Boga "twarzą w twarz", pragnienie to zostaje w pełni zaspokojone, a "serce" całkowicie uspokojone.

Bóg chciał, żeby człowiek szukał Go „z własnej ochoty i Jego się trzymał, dobrawolnie dochodził do pełnej i błogosławionej doskonałości... ale - jak wyjaśnia Konstytucja Gaudium et spes - wolność ludzka, zraniona grzechem, jedynie z pomocą łaski Bożej może to nastawienie ku Bogu uczynić w pełni skutecznym" (KDK 17). Po fakcie grzechu zrealizowanie tęsknoty za wspólnotą z Bogiem i uczestniczeniem w Jego szczęściu dokonać się może jedynie przy pomocy łaski, wysłużonej przez Jezusa Chrystusa w odkupieńczym Jego dziele.

\section{WSPÓLNOTOWY ASPEKT POWOEANIA W DZIELE ODKUPIENA CHRYSTUSOWEGO}

Podobnie jak w akcie stworzenia Bóg przeznaczył i powołał do udziału w swoim życiu i szczęściu całą ludzkość jako społeczność, tak i po upadku grzechowym Pan Bóg, zsyłając na świat swego Jednorodzonego Syna, przychodzi ze zbawienną pomocą nie odizolowanym od siebie jednostkom, ale całej społeczności ludzkiej. „Stąd - w formie wniosku wyjaśnia Konstytucja Gaudium et spes - od początku historii zbawienia wybierał (Bóg) ludzi nie tylko jako jednostki, ale i jako czlonków pewnej społeczności... Ten wspólnotowy charakter osiąga swoją doskonałość i wypełnia się w dziele Jezusa Chrystusa” (KDK 32). „Tajemnica człowieka - stwierdza tenże Sobór - wyjaśnia się naprawdę dopiero w tajemnicy Słowa Wcielonego... Chrystus, nowy Adam, już w samym

${ }_{16}$ Stownik teologii biblijnej. Tłumaczył i opracował Ks. K. Romaniuk, PoznańWarszawa 1973, 765.

17 Art. cyt., $57 \mathrm{n}$. 
objawieniu tajemnicy Ojca i Jego miłości objawia w pełni człowieka samemu człowiekowi i okazuje mu najwyższe jego powołanie” (KDK 22).

W chwili W c i e le n i a Syn Boży, przyjmując naturę ludzką, stał się członkiem ludzkiej społeczności, ale również - konsekrowany w tym momencie na Jedynego i Najwyższego Kapłana - stał się urzędowym przedstawicielem całej społeczności ludzkiej wobec Boga. „Syn Boży przez swoje Wcielenie - wyjaśnia Sobór — zjednoczył się w pewien sposób z każdym człowiekiem..., stał się prawdziwie jednym z nas, we wszystkim do nas podobny oprócz grzechu" (KDK 22).

Wspólnotowa solidarność Jezusa Chrystusa z całą społecznością ludzi, zapoczątkowana w chwili Wcielenia, ujawnia się w Jego ziemskim życiu, w czasie którego włączył się w życie współczesnej Jemu społeczności ludzkiej (por. KDK 32) ${ }^{\mathbf{1 8}}$.

Wspólnotowy charakter zbawczego powołania ujawnia się szczególnie w powszechności odkupieńczego dzieła Jezusa Chrystusa. Obejmuje ono wszystkich ludzi, całą społeczność ludzką, a w jej ramach każdego poszczególnego człowieka.

„Lecz On obarczył się naszym cierpieniem... - mówi w proroczej wizji mesjańskiej Izajasz — On dźwigał nasze boleści... On był przybity za nasze grzechy... Jahwe zwalił na Niego winy nas wszystkich... Zacny mój Sługa usprawiedliwi wielu, ich nieprawości On sam dźwigać będzie" (Iz 53, 4 nn.). W cytowanym proroctwie zostaje wyraźnie podkreślone, że przyszły Mesjasz będzie występował w imieniu nas wszystkich, to znaczy w imieniu całej społeczności ludzkiej.

„Syn człowieczy nie przyszedł, aby Mu służono - wyjaśnia sam Chrystus określając cel swego ziemskiego życia - lecz aby służyć i dać swoje życie za wielu (anti pollos)" (Mk 10, 45).

Wspólnotowy charakter odkupienia Chrystusowego szczególnie mocno wyraził św. Paweł. ,Jeden jest Bóg, jeden też Pośrednik między Bogiem a ludźmi - wyjaśnia w 1 Tm 2,5 - człowiek Jezus Chrystus, który wydał siebie samego na okup za wszystkich", to znaczy za całą ludzką społeczność. Jak pierwsze przestępstwo, pierwszy grzech stał się smutnym dziedzictwem całej społeczności ludzkiej, ,tak czyn sprawiedliwy Jego (tzn. Chrystusa) sprowadza - według Apostoła Narodów - na wszystkich ludzi usprawiedliwienie dające życie" (Rz 5, 18). Chrystus zespala wszystkich ludzi w jedną społeczność, w społeczność odkupionych.

$\mathrm{Na}$ tej podstawie Kościół stale odrzucał poglądy, które wyłączały kogokolwiek z ludzi z zasięgu odkupieńczego dzieła Chrystusowegc, ograniczając je tylko do przeznaczonych czy wierzących ${ }^{19}$. Zakres zbawczego

1. Por. J. Galot, Consecration au coeur du monde, Paris (1967) 150.

$19 \mathrm{~Np}$. papież Innocenty $\mathrm{X}$ potępił jedno ze zdań Janseniusza $\mathrm{z}$ tego właśnie powodu, por. DS 2005. 
dzieła Chrystusowego obejmuje - jak przypomina Sobór — ,nie tylko wiernych chrześcijan, ale także wszystkich ludzi dobrej woli, w których sercu działa w sposób niewidzialny łaska. Skoro bowiem - uzasadnia Konstytucja Gaudium et spes - za wszystkich umarł Chrystus i skoro ostateczne powołanie człowieka jest rzeczywiście jedno, mianowicie boskie, to musimy uznać, że Duch Święty wszystkim ofiarowuje możność dojścia w sposób Bogu wiadomy do uczestnictwa w tej paschalnej tajemnicy" (KDK 22). Wszyscy ludzie mogą zrealizować swoje ostateczne, boskie powołanie jedynie przez uczestnictwo $\mathrm{w}$ tajemnicy paschalnej, a to dlatego, ponieważ ,dzieła odkupienia ludzi... dokonał Chrystus Pan głównie - jak wyjaśnia Sobór - przez paschalne misterium swojej błogosławionej Męki, Zmartwychwstania i chwalebnego Wniebowstąpienia" (KL 5).

Ostateczne powołanie człowieka do wspólnoty z Bogiem i do udziału w Jego szczęściu staje się teraz powołaniem do w spólnoty z Chrystusem, z Jego odkupieńczą tajemnicą paschalną. „Wszyscy ludzie - oświadcza Konstytucja Lumen gentium - powołani są do tego zjednoczenia z Chrystusem, który jest światłością świata i od którego pochodzimy, dzięki któremu żyjemy, do którego zdążamy" (KK 3). Tylko w łączności z Chrystusem może, w obecnej ekonomii zbawienia, człowiek zrealizować swoje wezwanie do wspólnoty z Bogiem. Na płaszczyźnie zbawienia, na płaszczyźnie łaski człowiek jest bowiem całkowicie i bezwzględnie zależny od Chrystusa, co stwierdził sam Jezus w przypowieści wyrażającej zależność człowieka od Niego przez wskazanie na zależność latorośli od krzewu winnego, kończąc ją oświadczeniem: „beze Mnie nic uczynić nie możecie" ( $J$ 15, 5). Na płaszczyźnie zbawienia człowiek, bez łączności z Chrystusem, nic nie może uczynić, cóż dopiero mówić o dojściu - bez zjednoczenia z Chrystusem - do uczestniczenia w życiu i szczęściu Boga.

Powołanie człowieka do uczestniczenia w życiu i szczęściu Boga staje się powołaniem chrześcijańskim, ponieważ zostaje ponowione przez Chrystusa i może być zrealizowane tylko przez Chrystusa i w łączności z Chrystusem. „Wszystko jest wasze, wy zaś Chrystusa - stwierdza św. Paweł - a Chrystus Boga" (1 Kor 3, 22). Aby dojść do zjednoczenia z Bogiem, jak wynika z powyższego stwierdzenia, trzeba być przy Chrystusie i w Chrystusie, trzeba - jak podkreśla Y. C o n g a r ${ }^{20}-$ dostrzegać głęboki związek między odkupieniem a stworzeniem i odwrotnie.

Pierwotne powołanie człowieka zostało na nowo podjęte przez Chrystusa i dopełnione w Jego odkupieńczym dziele, przez które wszycy ludzie zostają wezwani do wkroczenia na drogę zbawienia, a powołanie do

20 Jalons pour une théologie du laïcat, Paris 1964, 594. 
wspólnoty z Bogiem wyrażającej się w uczestniczeniu w Jego życiu i szczęściu, zostaje uzupełnione powołaniem do wspólnoty z Chrystusem (Pawłowe ,en Xristo”). Wszyscy zaś odkupieni przez Chrystusa, przez to samo, zostają złączeni nową wspólnotową więzią, więzią odkupienia.

Nie wydaje się potrzebne szersze omawianie tego zagadnienia. Wystarczy przypomnieć twierdzenie Soboru: „Do Niego (tzn. do Chrystusa) upodabniać się winny wszystkie członki, aż ukształtuje się w nich Chrystus (por. Gal 4, 19). Dlatego też dopuszczeni jesteśmy do tajemnic Jego życia, z Nim współukształtowani, wespół z Nim umarli i wespół z martwych wskrzeszeni, aż wespół z Nim panować będziemy..." (KK .7).

Wnioskiem będzie stwierdzenie, żẻ również i na tym etapie powołanie człowieka, chrześcijańskie powołanie, ma wyraźnie charakter ws pólnotowy, ponieważ zbawcze dzieło odkupienia Chrystusowego skierowane jest do całej społeczności ludzkiej, a wspólnoty z Bogiem (przez udział w Jego życiu i szczęściu) nie może człowiek osiągnąć bez równoczesnej łączności i wspólnoty z Chrystusem. Zaś ci wszyscy, którzy łączą się z Chrystusem, nie pozostają obojętni wobec siebie ale łączą się wzajemnie, i to bardzo ściśle, tworząc mistyczne Ciało Chrystusa. Ale to prowadzi do następnego i ostatniego etapu kształtowania się chrześcijańskiego powołania, a mianowicie powołania do Kościoła.

\section{WSPÓLNOTOWY CHARAKTER POWOEANIA DO KOSCIOEA}

„Podobało się Bogu uświęcać i zbawiać ludzi nie pojedynczo — oświadcza Sobór - z wykluczeniem wszelkiej między nimi więzi lecz uczynić z nich lud..." (KK 9). Oto geneza powołania do życia Ludu Bożego Kościoła. O jego powstaniu zadecydowała wolna Boża decyzja. „Przedwieczny Ojciec, na skutek najzupełniej wolnego i tajemnego zamysłu swej mądrości i dobroci... wierzących w Chrystusa - wyjaśnia Konstytucja Lumen gentium - postanowił zgromadzić w Kościele świętym..." (KK 2). „Bóg powołał zgromadzenie tych, co z wiarą spoglądają na Jezusa, sprawcę zbawienia i źródło pokoju oraz jedności i ustanowił Kościołem, aby ten Kościół był dla wszystkich razem i dla każdego z osobna widzialnym sakramentem owej zbawczej jedności" (KK 9), to znaczy wewnętrznego zjednoczenia $z$ Bogiem.

Kościół, z woli Boga, ma być widzialnym sakramentem czyli znakiem i narzędziem zbawczego zjednoczenia z Bogiem, naprzód dla całej społeczności ludzkiej, a następnie dla każdego człowieka: „dla wszystkich razem i dla każdego z osobna".

$\mathrm{Z}$ tego powodu człowiek nie może zrealizować swego zbawczego, chrześcijańskiego powołania bez złączenia się z Kościołem. Taka jest katolicka nauka objawiona, którą przypomina Konstytucja Lumen gentium, 
kiedy uczy, że „ten pielgrzymujący Kościół konieczny jest do zbawienia. Chrystus bowiem jest jedynym Pośrednikiem i drogą zbawienia - uzasadnia Sobór - On ... potwierdził równocześnie konieczność Kościoła, do którego ludzie dostają się przez chrzest jak przez bramę. Nie mogliby tedy być zbawieni ludzie - wnioskuje Konstytucja - którzy wiedząc, że Kościół został założony przez Boga za pośrednictwem Chrystusa jako konieczny, mimo to nie chcieliby bądź przystąpić do niego, bądź w nim wytrwać". (KK 14).

Zbawcze powołanie całej ludzkości do Kościoła w jego pielgrzymującej widzialnej społeczności, ma swoje źródło w wolnej decyzji Boga, ale odpowiada również prawom rozwoju osoby ludzkiej, która może się rozwijać prawidłowo tylko w odpowiednim środowisku społecznym. „Człowiek bowiem z głębi swej natury jest istotą społeczną - stwierdza Konstytucja Gaudium et spes - toteż bez stosunków z innymi ludźmi nie może żyć, ani rozwinąć swoich uzdolnień" (KDK 12).

Idąc za myślą św. Tomasza ${ }^{21}$ można dopatrywać się podobieństwa między naturalnym życiem człowieka i rządzącymi nim prawami a nadprzyrodzonym życiem łaski i jego rozwojem. Człowiek rodzi się jako jednostka (osoba) ale równocześnie, przez samo narodzenie, staje się członkiem ludzkiej społeczności. Czyli już same narodziny mają swój wymiar społeczny i wspólnotowy. Podobnie jest i w życiu łaski. Normalnie rozpoczyna je człowiek z przyjęciem sakramentu chrztu. Ale przez przyjęcie chrztu staje się on członkiem społeczności Kościoła.

Chrzest, rozpoczynający boskie życie w człowieku jako jednostce, jest wydarzeniem ściśle osobowym ale zarazem - jak zauważa M. D. Chenu ${ }^{22}$ - ma on wymiar ws pólnotowy, ponieważ włącza do wspólnoty mistycznego Ciała Chrystusa czyli Kościoła. Dlatego obowiązek przyjęcia sakramentu chrztu i zarazem powołanie do niego są tak samo powszechne jak powołanie do Ludu Bożego.

Przez chrzest wierny zostaje włączony do wspólnoty Kościoła, w której znajduje odpowiednie środowisko i wszystkie potrzebne mu pomoce do rozwijania powołania $\mathrm{chrzc}$ iel $\mathrm{nego}$, to znaczy dążenia do zbawienia przez uświęcanie się, przez dążenie do doskonałości. „Wyposażeni w tyle i tak potężnych środków zbawienia — stwierdza Konstytucja Lumen gentium - wszyscy wierni chrześcijanie jakiejkolwiek sytuacji życiowej oraz stanu powołani są przez Pana, każdy na właściwej sobie drodze, do świętości doskonałej, jak i sam Ojciec doskonały jest" (KK 11).

Te potężne środki zbawienia, to przede wszystkim sakramenty święte. „Podobnie jak ludzkie ciało - wyjaśniał papież Pius XII - posiada

21 Pisze na ten temat np. w Opusculum 15, De articulis fidei et Ecclesiae sacramentis, wyd. Vives, t. 27, 171-178.

22 Vocations particulierès et grâce baptimale, w: La vocation religieuse et sacerdotale, Paris (1969) 17. 
własne narządy, dzięki którym dba o własne jak i poszczególnych członków życie, zdrowie i wzrost, tak i Zbawca rodzaju ludzkiego w nieskończonej swej dobroci mistycznemu Ciału swemu w przedziwny zaradził sposób wzbogacając je sakramentami, które by stopniowo, niby nieprzerwanym szeregiem łask, członki od kolebki do ostatniego tchnienia podtrzymywały i równocześnie zaradzały przeobficie potrzebom społecznym całego Ciała" 23. Coraz częściej dochodzi do głosu społeczny, wspólnotowy wymiar sakramentów, których celem ,jest uświęcanie człowieka”, ale i „budowanie mistycznego Ciała Chrystusa” (KL 59).

Nie każda łączność ze wspólnotą Kościoła, nawet zapoczątkowana przez chrzest, prowadzi niezawodnie do zrealizowania ostatecznego powołania chrześcijańskiego, jakim jest osiągnięcie zbawienia. Przypomina Sobór, że „nie dostępuje jednak zbawienia, choćby był wcielony do Kościoła, ten, kto nie trwając w miłości, pozostaje wprawdzie w łonie Kościoła ciałem ale nie sercem" (KK 14).

Powyższe stwierdzenie wskazuje, że Kościół - gdy chodzi o zjednoczenie i więzi łączące jego członków - ma inną naturę niż ludzkie społeczności naturalne. Wskazał to wyraźnie już papież Pius XII, kiedy wyjaśnił, że najgłębszą podstawą zjednoczenia w Kościele jest nie tylko wspólny cel oraz zespolenie wszystkich w dążeniu ku temu celowi, jak to bywa w naturalnych społecznościach ludzkich, ale jest nią Duch Swięty, który - jeden i ten sam co do liczby - cały Kościół napełnia i jednoczy ${ }^{24}$. Również Konstytucja Lumen gentium, w nawiązaniu do przytoczonej wypowiedzi papieża Piusa XII stwierdza, że „wszyscy wierni rozproszeni po całym świecie mają ze sobą łączność w Duchu Świętym i w ten sposób mieszkaniec Rzymu - uczy Sobór za św. Janem Chryzostomem wie, że Hindusi są członkami tego samego co on organizmu" (KK 13). Oparte na Duchu Swiętym, jako ostatecznym źródle, zjednoczenie wszystkich wiernych w Kościele nazywa Sobór ws pólnotą- com mun ị o (por. KDK 32).

Nie wnikając głębiej w samo pojęcie Kościoła jako wspólnoty, które tak mocno doszło do głosu na ostatnim Soborze, a o czym dość obszernie i dogłębnie pisze ks. kard. K. Wojtyła ${ }^{25}$, wystarczy podkreślić tylko wzajemną łączność i współzależność wszystkich członków Kościoła. W tej łączności i współzależności uwidacznia się bowiem najbardziej wspólnotowy charakter, w kierunku horyzontalnym, powołania chrześcijańskiego.

U podstaw wzajemnej łączności i współzależności poszczególnych wier-

23 Encyklika Mystici Corporis, AAS 35 (1943) 201. Tłumaczenie polskie według wydania - Kraków 1944, (Wydawnictwo Głosu Karmelu), s. 17.

24 Tamże, 203; Tłum. polskie, 50.

$25 \mathrm{Dz}$. cyt., $105 \mathrm{nn}$. Na ten temat piszą także: Ks. R. Eukaszczyk, Kościót jako wspólnota $w$ Chrystusie, ,Zeszyty Naukowe KUL", 12 (1969) $13 \mathrm{nn}$; Ks. J. Krucina, W spólnota strukturalna Kościoła, „Znak”, 20 (1968) $1103 \mathrm{nn}$. 
nych leży wzajemna łączność i współzależność różnego rodzaju wspólnot w ramach Kościoła powszechnego. Kościół tworzy i musi tworzyć rozmaite, większe i mniejsze wspólnoty, przez które wierni mogliby żyć życiem Kościoła i w nich się uświęcać. Każda taka wspólnota nie może być jednak zamknięta w sobie i dla siebie, ale ma być uobecnianiem całej wspólnoty Kościoła w danym miejscu ${ }^{26}$ oraz musi mieć na względzie dobro i rozwój całego Kościoła. Zachodzi bowiem ścisła w s p ó z z a le żnoś ć między tymi wspólnotami jako częściami, a społecznością Ludu Bożego jako całością i odwrotnie. Konstytucja Lumen gentium, nawiązując do katolickości Kościoła w sensie intensywnym, stwierdza, że „,poszczególne części przynoszą innym częściom i całemu Kościołowi właściwe sobie dary tak, iż całość i poszczególne części doznają wzrostu na skutek wzajemnej łączności wszystkich oraz dążenia do pełni w jedności" (KK 13). Jest to tzw. w s póln o t a Kości ołów - communio Ecclesiarum 27 - o której Sobór mówi, że „we wspólnocie kościelnej prawomocnie istnieją partykularne Kościoły, oraz że między poszczególnymi częściami Kościoła istnieją więzy głębokiej wspólnoty co do bogactw duchowych, pracowników apostolskich - a nawet - i doczesnych pomocy. Albowiem ... również do poszczególnych Kościołów odnoszą się słowa Apostoła: „Jak każdy otrzymał łaskę, tak niech usługuje jeden drugiemu na wzór dobrych szafarzy rozlicznej łaski Bożej" (1 P 4, 10) (KK 13).

Wzajemną łączność i współzależność, jaka zachodzi między poszczególnym wiernym a pozostałymi wiernymi i całością Kościoła, pojmować można tylko w oparciu o stwierdzenie św. Pawła, że w Kościele Chrystusowym, pojętym jako Jego Ciało, ,,jedni są członkami drugich” (Ef 4, 25; por. 1 Kor 12, 21-26). Na tej podstawie cały Kościół odczuwa dobro lub zło, jakie znajduje się w każdym poszczególnym wiernym, a każda czynność wiernego wpływa na całe Ciało Chrystusa, czyli na cały Kościół 28. Stąd coraz częściej i wyraźniej wraca się właściwie do tradycyjnej nauki o wspólnotowych czy społecznych wymiarach zarówno dobrych czynów jak i grzechu poszczególnego wiernego.

Grzech, w istocie swojej, to obraza wyrządzona Bogu i zerwanie z Nim przyjaźni. Ale na mocy współzależności wszystkich wiernych $\mathrm{s} z \mathrm{kodzi}$ on również całej ws póln o c i e Kościoła. Skoro Konstytucja Lumen gentium wyjaśnia, że wierni, „którzy przystępują do sakramentu pokuty, otrzymują od miłosierdzia Bożego przebaczenie zniewagi wyrządzonej Bogu i równocześnie dostępują pojednania z Kościołem, któremu grzesząc zadali ranę" (KK 11), to znaczy, że grzech jest nie tylko

26 Por. Ks. R. Łukaszczyk, art. cyt., $16 \mathrm{n}$.

$2 \pi$ Por. Ks. kard. K. Wojtyła, dz. cyt., $121 \mathrm{n}$.

28 J. Galot, Ciało mistyczne (z j. francuskiego tłum. przez S. Nawiedzenia N.M.P. w Jaśle), Warszawa 1964, $121 \mathrm{nn}$. 
zniewagą Bogu wyrządzoną, ale również naruszeniem jedności z Kościołem, a nawet zadaniem rany Kościołowi czyli całej wspólnocie wiernych.

Chrześcijańskie powołanie, to nie tylko wezwanie do niegrzeszenia, ale także powołanie do czynnej realizacji dobra, albowiem ,„...wszyscy w Kościele... powołani są do świętości - wyjaśnia Sobór zgodnie ze słowami Apostoła: „Albowiem wolą Bożą jest uświęcenie wasze" (1 Tes 4, 3) (KK 39) i do wzajemnego świadczenia sobie usług ,wedle różnych darów sobie udzielonych" (KDK 32) ${ }^{29}$. Na tej płaszczyźnie otwierają się szerokie perspektywy i wielkie możliwości do udzielania osobistej odpowiedzi ze strony każdego poszczególnego człowieka, na Boże wezwanie. Przy czym wzrost $\mathrm{w}$ osobistej świętości przyczynia się również do świętości całego Kościoła, który staje się tym samym coraz bardziej Kościołem „bez skazy czy zmarszczki” oraz „nieskalany i święty” (Ef 5, 27).

Wspólnotowy charakter powołania do Kościoła ujawnia się także w zobowiązaniu, jakie z niego wynika, do troski o przyjęcie i rozwijanie daru Bożego powołania przez wszystkich wezwanych do zbawienia, w tym duchu jak pisze św. Paweł: „teraz raduję się w cierpieniach i za was ze swej strony w moim ciele dopełniam braki udręk Chrystusa dla dobra Jego Ciała, którym jest Kościól” (Kol 2, 24). Dobry komentarz do słów Pawłowych stanowi upomnienie papieża Piusa XII z encykliki Mystici Corporis: „Zaiste straszliwa to tajemnica, o której nigdy rozważać nie będzie za wiele, a mianowicie, że zbawienie wielu zależy od modlitw i dobrowolnych umartwień członków mistycznego Ciała, podejmowanych przez nich w tej intencji, oraz od pomocnej współpracy pasterzy i wiernych"... 30 .

Wydaje się na podstawie przeprowadzonych refleksji, że są podstawy, aby $\mathrm{w}$ zakończeniu przyjąc wniosek stwierdzający wspólnotowy charakter chrześcijańskiego powołania, ponieważ: $1^{\circ}$ powolanie chrześcijańskie ma, jako cel, doprowadzić do wspólnoty (communio) z Bogiem, z Chrystusem i Jego Matką oraz wszystkimi zbawionymi (por. KK 49-51; 69); $2^{\circ}$ skierowane jest do całej społeczności ludzkiej jako takiej oraz do każdego poszczególnego człowieka w ramach tej społeczności; $3^{\circ}$ powołania chrześcijańskiego nie można inaczej zrealizować, to znaczy nie można osiągnąć jego celu jak tylko we wspólnocie i przez wspólnotę Ludu Bożego czyli Kościoła.

Właśnie dlatego, że chrześcijańskie powołanie realizuje się we wspólnocie Ludu Bożego, może ono przybierać i faktycznie przybiera, roz-

29 Por. Ks. B. Inlender, art. cyt., 205.

30 Encyklika Mystici Corporis, 213. Tłum. polskie, $35 \mathrm{n}$. 
maite, szczegółowe formy ${ }^{31}$. Wielkość konkretnych, szczegółowych form powołania chrześcijańskiego wynika czy wyrasta z rzeczywistości wspólnoty (communio) Ludu Bożego. Różne potrzeby tej wspólnoty określają dokładniej rodzaj czy gatunek powołania chrześcijańskiego (por. DK 6; KK 11), i w ten sposób wspólne i ogólne powołanie chrześcijańskie znajduje swoje dopełnienie w osobistym, szczegółowym powołaniu każdego ochrzczonego, który - stosownie do różnych darów jemu udzielonych (por. KDK 32) - inne ma zadania do spełnienia we wspólnocie Ludu Bożego.

31 Ks. kard. K. Wojtyła (dz. cyt., 123) pisze, że wspólnota (communio) Ludu Bożego wynika $\mathrm{z}$ wielości powołań, ale - jak wynika $\mathrm{z}$ dalszych jego analiz - stwierdzenie jest odwracalne i można powiedzieć, że wielość czy różnorodność powołań wynika ze wspólnoty Ludu Bożego.

THE THEOLOGY OF CHRISTIAN VOCATION IN ITS COMMUNAL DIMENSION

\section{S U M M A R Y}

Christian vocation may be defined, chiefly according to the doctrine of the Second Vatican Council, as a natural and supernatural ability, given to man by God in the act of creation and redemption, enabling him to participate in the life and happiness of God. The communal character of Christian vocation thus conceived is manifest in all the stages of its planning and realization.

In the act of creation man received a communal nature, for he was called and destined not only to community with people, but to communion with God Himself. The communal character of Christian vocation is further revealed in the solidarity of Jesus Christ with the whole human society and in the catholicity of his redemptive work. The communion and interdependence of all believers in Jesus Christ who form the community of God's people is the further manifestation of the communal aspect of the Christian vocation. The diversity of needs of that People influences the concrete, detailed form of the Christian vocation (e. g. priestly, religious, family, etc.) of each faithful. 